\title{
Metafora verkkokeskusteluympäristössä
}

Tutkin tässä artikkelissa sitä, kuinka metaforaa käytetään "retorisena työkaluna" tekstipohjaisessa verkkokeskusteluryhmässä. Artikkelin empiirinen aineisto koostuu amerikkalaisen Darwin Awards -sivuston verkkokeskusteluryhmän keskustelusta, joka käytiin kuuden ensimmäisen syyskuun yhdennentoista päivän terrori-iskuja iskuja seuranneen tunnin aikana. Syyskuun 2001 terrori-iskut eivät siis itsessään ole tutkimuksen aihe vaan se, miten tapahtumia työstettiin tutkimuksen kohteena olleessa verkkokeskusteluryhmässä.

Darwin Awards -sivusto on alun perin perustettu listaamaan ympäri maailmaa tapahtuneita kuolemantapauksia, joissa uhrin oma ymmärtämättömyys on vaikuttanut hänen kohtaloonsa merkittävällä tavalla. Alkujaan Darwin-sivusto on Stanfordissa molekyylibiologiaa opiskelleen tutkija Wendy Northcuttin vuonna 1994 perustama foorumi traagisille mut-

Artikkelissa tutkitaan sitä, kuinka metaforaa käytetään "retorisena työkaluna" tekstipohjaisessa verkkokeskusteluryhmässä. Artikkelin empiirinen aineisto koostuu amerikkalaisen Darwin Awards -sivuston verkkokeskusteluryhmän keskustelusta, joka käytiin kuuden ensimmäisen syyskuun yhdennentoista päivän 2001 terrori-iskuja iskuja seuranneen tunnin aikana. Lähtökohtana on, että metaforan kaltaisista retorisista "suhteuttamisen työkaluista" tulee ilmaisukeinoja, joita käyttämällä kirjoittaja voi johdattaa keskustelua haluamaansa suuntaan. Tuolloin verkkokeskusteluryhmästä tulee kamppailun tila, jossa kilpaillaan siitä, kuka kulloinkin valitsee käytettävät käsitteet, metaforat ja niiden merkitykset. ta samaan aikaan jollakin tavoin humoristisille tarinoille ihmisten ajattelemattomuudesta ja sen seurauksista. Kuten sivustolla kuvaillaan, jos joku henkilö pitää mustana huumorina sitä, että laskuvarjohyppyä kuvaamaan lentokoneesta hypännyt henkilö sai surmansa, koska oli unohtanut ottaa itselleen laskuvarjon, myös Darwin-sivuston tarinoita voi pitää hauskoina. Aluksi sähköpostin välityksellä levinneestä muutaman kymmenen ihmisen joukkokirjeestä on myöhemmin kehittynyt myös kaupallista toimintaa. Northcutt toimii nykyisin sivuston täysipäiväisena toimittajana, ja Darwin-tarinoista on tehty $\mathrm{mm}$. kolme Northcuttin toimittamaa kokoelmakirjaa (Northcutt [toim.] 2001; 2003; 2004) sekä lukuisia lehtiartikkeleita (esim. Peltola 2000).

Darwin-sivuston englanninkielisessä verkkokeskusteluosiossa (Philosophy Forum) käsitellään lähinnä politiikkaan, filosofiaan ja uskontoon liittyviä teemoja. Keskusteluja voi lukea kuka tahansa, mutta niihin osallistuminen vaatii rekisteröitymisen kyseisen palvelun käyttäjäksi. Jokaisella keskusteluosiolla on myös omat ylläpitäjänsä, jotka voivat tarvittaessa sulkea keskustelun jostakin sopimattomaksi katsotusta aiheesta. Kuka tahansa rekisteröitynyt käyttäjä voi sen sijaan aloittaa keskustelun mielenkiintoiseksi katsomastaan teemasta. Sivuston keskus- 
teluryhmissä käytetään itse valittua nimimerkkiä, joka ei saa olla sama kuin toisella rekisteröidyllä käyttäjällä. Käyttäjät voivat halutessaan liittää nimimerkkinsä yhteyteen tietoja itsestään, mutta yleisesti ottaen keskustelijoista ei ole saatavissa taustatietoa sivustolla. Sen sijaan muilta käyttäjiltä saattaa tulla "oikeita", heidän omalla nimellään lähetettyjä sähköposteja, jotka eivät näy Darwin-sivustolla.

Sivuston käyttösäännöstössä todetaan, että Darwin-foorumilla on tarkoitus käydä "älykästä ja rationaalista keskustelua", ja sivustolla jokainen käyttäjä voi "oppia asioita eri ikäisiltä ja koulutustaustaisilta ihmisiltä monista eri maista" (Darwin Awards Member Guidelines). Säännöissä korostetaan myös, että koska keskustelijat ovat teemoista usein hyvinkin eri mieltä, "on tärkeää tietää, kuinka ollaan eri mieltä siten, että keskustellaan asia-argumenteista henkilöargumenttien sijaan" (mt.). Sivuston ylläpito (moderating) karsii asiattomat viestit varsin pian pois. Käyttäjäksi rekisteröityminen on jo sinänsä kynnys, jonka ylittäminen vaatii hieman pitkäjänteisempää kiinnostusta keskusteluryhmää kohtaan. Darwin-foorumilta löytyy myös neuvoja erilaisten loogisten päättelyketjujen muodostamiseen ja seuraamiseen. Sivustolla käytävän keskustelun odotetaan siis olevan "asialliseksi" luokiteltavaa. Aktiivisesta ylläpidosta huolimatta lopullinen vastuu Darwin-sivuston verkkokeskustelujen laadusta ja sisällöstä on jätetty keskustelijoille itselleen. Kuten sivuston käyttösäännöstössä todetaan, ylläpitäjät eivät voi säilyttää avointa keskusteluilmapiiriä väkisin, vaan siihen tarvitaan jokaisen yksittäisen keskustelijan omaa henkilökohtaista panosta.

Bostonista noussut American Airlinesin lento numero 11 törmäsi World Trade Centerin pohjoiseen torniin itärannikon aikaa kello 8.45 tiistaiaamuna 11.9.2001. Ensimmäinen aihetta käsitellyt viesti ilmestyi Darwin-sivustolle 46 minuuttia myöhemmin keskusteluun, jonka yläotsikko oli "Bombings: World Trade Center". Seuraavien kuuden tunnin aikana keskusteluun tuli 200 aihetta tavalla tai toisella käsitellyttä viestiä, joiden 12 . syyskuuta sivustolta tulostetut versiot ovat tämän tutkimuksen empiirisenä aineistona. Kirjoittajia oli yhteensä 62, ja heistä kukin lähetti itärannikon aikaa 9.31-15.30 ryhmään 1-20 viestiä. Eniten oli yhden viestin lähettäjiä, ja yli kymmenen viestiä lähettäneitä käyttäjiä oli kolme. Suurin osa ryhmässä tuolloin olleista keskustelijoista oli Darwin-sivuston vakiokäyttäjiä. Ryhmään terrori-iskun jälkeen viestejä lähettäneet olivat jo aiemmin postittaneet eri keskusteluihin keskimäärin 791 viestiä per käyttäjä. Yli tuhat viestiä postittaneita oli jossakin vaiheessa kytkeytyneenä 17 kappaletta. Vain seitsemän keskustelijaa oli postittanut ryhmään aiemmin alle sata viestiä ja 50 prosenttia tuolloin ryhmässä olleista keskustelijoista oli rekisteröitynyt foorumin käyttäjäksi joko vuonna 2000 tai sitä aiemmin, joten suurin osa heistä oli ainakin jossakin määrin toisilleen.

\section{Metafora verkkokeskustelussa}

Käytän tässä artikkelissa George Lakoffin (1993) määritelmää, jonka mukaan metafora on jonkin kokemuksen alueen mallintamista jonkin toisen kokemuksen alueen sanaston avulla (Aro 1999, 42). Metafora muodostaa kytköksen menneen ja vielä hahmottumattoman tulevaisuuden kanssa samalla, kun sen kautta yritetään käsittää ja myös käsitteellistää nykyisyyttä ja rakentaa eri historiallisten tapahtumien kautta kulkevaa "pitkä linjaa" (Kuusisto 1999; Lakoff \& Johnson 1980; Pekonen 1991; Perelman 1982). Kun tätä ajatusta sovelletaan verkkokeskusteluryhmän kontekstissa, metaforan kaltaisista retorisista "suhteuttamisen työkaluista" tulee ilmaisukeinoja, joita käyttämällä kirjoittaja voi johdattaa keskustelua haluamaansa suuntaan. Verkkokeskusteluryhmän voi siis nähdä kamp- 
pailun tilana, jossa kamppaillaan siitä, kuka kulloinkin valitsee käsitteet, termit, metaforat ja niiden merkitykset (Pekonen 1991, 46-48).

Jari Aro korostaa, että Lakoffin metaforateoriassa tehdään erottelu käsitteellisen metaforan ja metaforisten ilmaisujen väliłlä (Aro 1999, 44). Hän huomauttaa, että Lakoff tarkoittaa käsitteellisellä metaforalla aina jonkin puheyhteisön konventionaalisia ja yleisesti jaettuja metaforisia määrittelyjä. Tässä artikkelissa "puheyhteisö" on kirjoitettuun tekstiin perustuva verkkokeskusteluyhteisö, ja hypoteesinani on, että verkkokeskustelun nopean tempon takia sekä metaforisilla ilmauksilla että käsitteellisillä metaforilla on tärkeä rooli siinä, miten keskustelu ryhmässä etenee. Artikkelissani tarkastellun yksittäisen verkkokeskustelun voi sanoa olevan oma "metaforamaailmansa", joka on kuitenkin jatkuvasti kytköksissä esimerkiksi muiden medioiden tarjoamiin metaforamaailmoihin. Nämä eri metaforamaailmat ovatkin paitsi keskenään verkottuneita niin myös jatkuvassa sisäisen muutoksen tilassa (Kuusisto 1999, 64; Lakoff \& Johnson 1980, 36).

Koska artikkelin tutkimusaineisto on rajattu koskemaan kuuden terrori-iskua seuranneen tunnin verkkokeskustelua, ei olisi mielekästä ottaa tarkastelun itsestään selväksi lähtökohdaksi valmiiksi rajattua aggressiivista "sodan" tai "taistelun" käsitettä. Sen sijaan pyrin tarkastelemaan lähemmin yleistä "metaforailmastoa", joka verkkokeskusteluryhmässä tuolloin vallitsi. Tutkimusaineisto keskittyy aikaan, jolloin syyskuun tapahtumiin liittyvät faktat olivat vielä "valmistusvaiheessa", eikä mitään yhtä tiettyä "virallista totuutta" tai "juurimetaforaa" (esim. sota terrorismia vastaan) tapahtumista vielä ollut. Verkkokeskustelun kirjoittajien käyttämät metaforat sijoittuvat tässä mielessä oman käsityskyvyn ja jonkin yhteiseksi koetun välimaastoon, jolloin metaforat ovat myös työkaluja "oman totuuden" muodostamista ja ilmaisemista varten. Samalla tutut, arkikieleen sulautuneet metaforat ja käsitteet voivat saada uusia merkityksiä ja tulla osaksi uusia keskustelunavauksia. (Aro 1999, 45; Palonen 1998, 182-184; Perelman 1982, 123-125.) Tuolloin verkkokeskustelunkin puheenvuoroista ja niissä käytetyistä metaforista tulee tekstin tulkinnan kohteita, jotka eivät ole kirjoittajiensa ajatusten suoria ilmauksia vaan verkkokeskustelun kontekstissa tapahtuvia tekoja (Palonen 1988, 20-21).

\section{Verkkokeskusteluryhmä toimintatilana}

Tietoverkoissa keskustelijat eivät jaa samaa fyysistä tilaa keskustellessaan, mikä tekee verkkokeskustelusta eräänlaisen "pseudoyhteisön". Reijo Savolainen (1996) on todennut, että verkkokeskustelujen käytännön maailma pohjautuu pitkälti "talking by writing -ideaan", jossa kirjoittamisen välillä tapahtuva kommunikaatio on luonteeltaan nopeatempoista. Yksittäisen viestin kirjoittaminen vie harvemmin muutamia minuutteja kauempaa, ja verkkokeskusteluille onkin tyypillistä impulsiivisuus ja nopea aiheesta toiseen siirtyminen. Verkkokeskusteluja demokraattisen prosessin näkökulmasta tutkinut Veikko Pietilä (2002) mainitsee, että optimistinen näkemys tietoverkoista pitää niitä suurena "elektronisena foorumina" tai "kybertilana", jota voisi verrata esimerkiksi katukahviloihin. Toisaalta Pietilä toteaa Savolaisen tavoin, että verkkokeskustelut eivät useinkaan ole kovin pitkäkestoisia, vaan aiheesta hypätään toiseen varsin pian.

Verkkokeskusteluryhmissä käytäville keskusteluille on ominaista tietynlainen rönsyilevyys ja myös lyhytjänteisyys (Savolainen 1996, 51). Toisaalta verkkokeskustelut muodostavat "lankoja" (thread), joita seuraamalla on mahdollista jäljittää keskustelun kulkua sen alkuun asti. Lähes jokaisella sivustolla tai keskusteluryhmällä on jonkinasteinen käyttösäännöstö, jotka saattavat erota toisistaan suures- 
tikin. Siinä missä yksi keskusteluryhmä vaatii rekisteröitymistä, jokin toinen ryhmä tarjoaa mahdollisuuden anonyymiin kommunikaatioon. Säännöstöt perustuvat joko käytännön toiminnan kautta saatuihin kokemuksiin tai tietyn verkkopalvelun tarjoajan omiin intentioihin (Lessig 2001, 35-36). Tietoverkkojen toimintakulttuuri on yhden selkeän säännöstön sijaan enemmänkin hajanainen kokoelma kansallisia lainsäädäntöjä sekä epävirallisia "käytöskoodistoja" (code of conduct) ja normeja (Peltola 2003a; 2003b). Lainsäädännölliset ongelmat kuten esimerkiksi yksityisyyden suoja, sananvapaus ja julkaisijan vastuu territoriaalisista rajoista riippumattomassa verkkokeskustelussa ovat nousseet monissa maissa keskustelun aiheiksi Internetin käyttäjämäärän voimakkaan kasvun myötä (Johnson \& Post 1998, 6-12; Mclntosh \& Cates 1998, 116-118; Raab 1998, 165-171). Kysymys keskustelun sisältöä koskevasta vastuusta onkin monitahoinen, koska verkkokeskusteluareenoilla palveluntarjoaja jää ajan kuluessa usein taka-alalle, ja keskustelijoiden rooli toiminnan tuottajana ja sen luonteen muokkaajana korostuu (Aarnio et al. 2001, 12). Verkkokeskustelujen toimijarakenne näyttäisikin olevan kolmen eri tekijän - palvelun tarjoajan, keskusteluryhmän ylläpitotahon sekä keskustelijoiden itsensä - muodostama kokonaisuus.

Tietoverkkojen keskusteluryhmän voi hahmottaa mielen tai mielikuvituksen tilana, joka rohkaisee keskustelijaa spekuloimaan erilaisilla ajatus- ja toimintamalleilla (Holmes 1997, 31). Tässä mielessä tietoverkot ovat julkisen keskustelufoorumin lisäksi yksityinen tila: verkossa ihmiset kykenevät työstämään ja testaamaan erilaisia näkemyksiä ympäristössä, joka on siihen tarpeeksi turvallinen ja jota pystyy itse joiltakin osin kontrolloimaan (Willson 1997, 146-148). Vasta tämän testausvaiheen jälkeen he voivat päättää näkemyksen sopivuudesta omaan tilanteeseensa "oikeassa" elämässä. Toisaalta tietoverkot eivät ole muusta maailmasta täysin erillinen toimintaympäristö, vaan muodostavat todellisten tapahtumien kanssa tietynlaisen rajapinnan, jossa erilaisia tapahtumia voidaan käsitellä. Kuten Simon Cooper (1997, 93-94) on huomauttanut, tämä näkemys poikkeaa "totaalisen virtuaalisuuden" ajatuksesta (esim. Heim 1993, 1998), jossa tietokoneilla luotu virtuaaliympäristö nähdään toimintatilana irrallaan "todellisesta" fyysisestä ympäristöstä.

Darwin-sivuston keskustelijat ovat sivustolle rekisteröityessään sitoutuneet tiettyihin verkkokeskustelua koskeviin käytäntöihin, jotka vaikuttavat osaltaan eri ryhmissä käytävien keskustelujen luonteeseen. Sivuston ylläpito voi tarvittaessa poistaa asiattomiksi katsotut tai toisia keskustelijoita henkilökohtaisesti loukkaavat viestit ja sulkea niitä lähettäneet käyttäjänimimerkit keskusteluista. Arthur R. Edwards (2002) on havainnut, että tällainen käytäntö voidaan nähdä sensuurin tai "suodattamisen" (filtering) sijaan myös keskustelua tukevana toimintana, koska se luo mahdollisuuksia toimivan keskusteluympäristön rakentumiseen. Edwards toteaa myös, että ylläpito on luonteeltaan pelkän sensuroinnin sijaan enemmän kokonaisvaltaista "manager-toimintaa", jolla on suuri merkitys keskusteluryhmän toimivuudelle. Verkkokeskusteluryhmän avoimuus on siis jonkinlaista "kontrolloitua avoimuutta", jossa käyttäjäverkosto toimii joko suoraan tai epäsuorasti ohjatussa ympäristössä.

\section{"Oikeuden tulee toteutua"}

Ensimmäinen syyskuun yhdennentoista päivän terrori-iskua käsitellyt viesti lähetettiin Darwin-sivuston keskustelupalstalle tiistaiaamuna itärannikon aikaa kello 9.31, noin 45 minuuttia ensimmäisen koneen syöksymisestä World Trade Centerin pohjoiseen torniin (CNN: September 11: Chronology of terror). Tuolloin myös toi- 
nen, American Airlinesin Bostonista noussut lento 175 oli törmännyt eteläiseen torniin kello 9.03, ja presidentti George W. Bush oli samoihin aikoihin aloittamassa televisiopuhettaan Sarasotassa Floridassa. Ensimmäinen, nimimerkin Bill lähettämä viesti sisälsi jo tiedon siitä, että kaksi lentokonetta on törmännyt WTC-torneihin. Viestissä todettiin myös, että kyseessä on "ilmeinen terrori-isku". Samalla kirjoittaja käyttää "oikeuden" (justice) toteutumisen metaforista ilmausta mahdollisia jälkiseurauksia analysoidessaan:

Jos tämä todella on terrori-isku, toivon nopeaa ja brutaalia oikeuden toteutumista niille, jotka suorittivat tämän mielettömän teon. (Nimimerkki Bill, kello 9.31 itärannikon aikaa, käännös kirjoittajan.)

Monista viesteistä käy ilmi, että syyskuun yhdennentoista päivän tapahtumat koettiin keskusteluryhmässä jonkin koskemattoman tai tietyllä tavalla "pyhän" loukkaamisena (esim. "Violation of America"). Heti keskustelun alettua ryhmässä oli ikään kuin valmiiksi omaksuttu jaettu käsitys siitä, että päivän traagisten tapahtumien jälkeinen poliittis-sotilaallinen aloitevalta on amerikkalaisilla, koska ennen iskuja vallinnut tila koettiin keskusteluryhmässä "normina", jota iskut järkyttivät ratkaisevalla tavalla. Mahdolliset seuraukset ja niiden mittakaava olivat useimpien ryhmän keskustelijoiden mielestä USA:n ja etenkin sen armeijan päätettävissä. Eräässä viestissä esiintyi jopa ilmaisu "Jumalan väliaikaisesta korvaamisesta" (suspend the concept of God in control), koska tämä nähtiin välttämättömänä "oikeuden" toteutumiseksi, ja viitattiinpa vastaiskua hahmotellessa myös islaminuskon pyhään sotaan (if it's Jihad they want it's Jihad they'll get). Myös voimankäytöstä varoittavissa viesteissä oli kristinuskoon viittaavia ilmaisuja kuten "joka miekkaan tarttuu, se miekkaan hukkuu" ja "valtatie helvettiin", joilla pyrittiin korostamaan, ettei mahdollinen vastaisku johtaisi haluttuun lopputulokseen. Toisaalta "liian rauhanomaisten" kommenttien lähettäjiä pidettiin "paholaisen asianajajina" (Devil's advocate).

Toinen selkeä päälinja oli tapahtuneen hahmottaminen järkeen tai tarkemmin järjen vastaisuuteen viittaavien metaforien kautta. Iskut olivat "mielettömiä" ja monissa viesteissä korostettiin, että tapahtuneesta huolimatta "ihmisyyttä" (humanity) ei saisi unohtaa. Voimakkaita vastatoimenpiteitä kannattaneissa viesteissä tämä näkyi siten, että tapahtumien katsottiin tehneen ihmisestä eläimen tai ainakin eläimellisen; iskut olivat "herättäneet nukkuvan karhun", oli "astuttu lohikäärmeen hännän päälle" ja "nukkuva jättiläinen" oli herätetty. Tapahtumille ja tulevalle mahdolliselle vastaiskulle etsittiin oikeutusta erilaisista aktiivisen toiminnan metaforisista ilmaisuista kuten esimerkiksi "on rikottava munia jos haluaa munakasta" tai "rikkaruohot on kitkettävä puutarhasta". Joissakin viesteissä rauhanomaisempia kannanottoja pidettiin heikkouden osoituksena, koska iskujen tekijöitä pidettiin lähtökohtaisesti epäinhimillisinä. Erään kirjoittajan sanoin, "yhtä hyvin voisi olla ystävällinen AIDS-virukselle". Tämän näkemyksen rinnalla ryhmässä oli samanaikaisesti kannattajia myös toisenlaiselle näkemykselle, jonka mukaan Yhdysvaltain hallitus ei ollut täysin osaton tuon aamun tapahtumiin, koska sen toimilla nähtiin olleen osuutta esimerkiksi Lähi-idän vuosia jatkuneeseen kriisiin.

\section{Sodanjulistus vai terrori-isku?}

Syyskuun yhdennentoista päivän tapahtumille alettiin Darwin-sivuston keskusteluryhmässä varsin nopeasti etsiä vertailukohtaa historiasta ja suhteuttaa niitä osaksi suurempaa kokonaiskuvaa. Ryhmässä pohdittiin esimerkiksi sitä, voisiko 
juuri tapahtuneita iskuja verrata vuonna 1941 Pearl Harborin tukikohtaan kohdistuneeseen sotilasiskuun. Tämä vertailu "sodanjulistuksen" ja "terrori-iskun" käsitteellisten metaforien välillä askarrutti monia ryhmään kirjoittaneista etenkin keskustelun alkuvaiheessa. Viesteistä käy selkeästi ilmi, että tapahtumat olisi ollut helpompi käsittää, jos iskut olisivat kohdistuneet sotilaskohteeseen. Esimerkiksi nimimerkin Blondine lähettämässä viestissä perheen kautta koettu henkilökohtainen taso yhdistyy tapahtumien sotilaalliseen puoleen ja tapahtumat käsitetään tämän ristiriidan kautta. Samalla myös Blondine rinnastaa iskut historiallisena tapahtumana Pearl Harborin hyökkäykseen:

\footnotetext{
Osa sukulaisistani työskentelee armeijassa, ja heistä tuntuu, että tämä isku oli sotatoimi ja joku joutuu maksamaan tästä. Heistä tuntuu, että tämä on samanlainen tapahtuma kuin Pearl Harbor, koska tekijät ovat tehneet jotakin, joka johtaa meidän mukaantuloomme. (Blondine, klo 11.39.)
}

Myöhemmin terrori-iskuja verrattiin keskustelussa $\mathrm{mm}$. operaatio Aavikkomyrskyyn (Operation Desert Storm, 1990), Oklahoman virastotalon räjäytykseen (1995) sekä Amerikan sisällissodan Gettysburgin taisteluun (1863). Perusteina näihin vertailuihin pidettiin uhrien lukumäärää.

Syyskuun yhdennentoista päivän aamuna käynnistyneestä tapahtumasarjasta on jälkikäteen käytetty ilmaisuja kuten "New Yorkin terrori-iskut" tai "WTC-iskut". Yhdysvalloissa tapahtumasarjaan viitataan monesti myös pelkällä numerosarjalla "9-11", koska 911 on Yhdysvalloissa yleinen hätänumero. Myös Darwinsivuston keskusteluryhmässä keskustelu tapahtumasarjan nimeämisestä alkoi varsin pian. Tapahtumapäivän päivämäärää pidettiin mahdollisesti merkityksellisenä asiana:

Tietääkö kukaan, onko hyökkäyksen päivämäärällä mitään merkitystä? Etsin asiaa netistä, ja ainoa löytämäni asia oli syyskuun 11. päivä 1970, jolloin Pinochet kaappasi vallan Chilessä. (mad marty, klo 10.24.)

Myöhemmin nimimerkki Insomniac toisti saman kysymyksen ja lisäsi, että terroristeilla on tapana ajoittaa iskut siten, että niillä on päivämäärän kannalta merkitystä. Tässä vaiheessa ryhmässä oli siis suurelta osin omaksuttu yhteinen näkemys siitä, että kyseessä oli nimenomaan terrori-iskujen sarja. Ei voi kuitenkaan sanoa, että tapahtumasarja olisi hahmottunut keskusteluryhmässä kuuden ensimmäisen tunnin aikana käydyn keskustelun perusteella vielä sellaiseksi kokonaisuudeksi, jota olisi selkeästi kutsuttu yhdellä tietyllä nimellä. Ilmaisut kuten "the WTC attacks", "the Twin Towers attacks" sekä "Attack on Pentagon" vilahtelivat eri viesteissä, mutta mitään varsinaista yhteistä käsitettä tapahtumasarjalle ei keskustelussa vielä ollut.

Pohjoisen WTC-tornin romahdettua kello 10.28 keskusteluryhmään lähetetty, muista lähteistä peräisin oleva informaatio saavutti tietynlaisen saturaatiopisteen. Tuolloin nimimerkki BCE postitti keskusteluryhmään pitkän, CNN-yhtiön verkkosivuilta peräisin olevan uutisen, jossa oli siihenastiset tapahtumat koottuna yhteen viestiin. Samalla CNN-sivuston informaatio hyväksyttiin ryhmässä ikään kuin virallisena näkemyksenä tapahtumien kulusta. Tämän jälkeen lähetetyt viestit käsittelivät yhä useammin erilaisia teknisiä yksityiskohtia kuten verenluovuttamista tai ison matkustajakoneen ohjaamisen vaikeutta. Samalla viestien sisällön perusteella voi todeta, että verkkokeskusteluryhmästä tuli vähitellen käyttäjilleen informaation saannin primäärifoorumi ja muut informaatiolähteet jäivät taustalle. Myös muiden ryhmään lähetettyjen viestien kommentointi lisääntyi pelkkien omien havaintojen "ylöskirjaamisen" ja julkaisemisen sijaan.

Kolme tuntia ensimmäisen iskun jälkeen lähetetyt viestit olivat jo sen tyylisiä, 
että niistä ei voi suoraan päätellä, mitä oikeastaan oli tapahtunut, koska keskustelu oli siirtynyt sen verran yksityiskohtaiselle tasolle. Esimerkiksi kello 12.47, neljä tuntia ensimmäisen iskun jälkeen, nimimerkki Ander Kryst lähetti viestin, jossa hän rinnasti aamun tapahtumat Nostradamuksen ennustuksiin, ja tätä seuraavat kommentit keskittyivät enemmän Nostradamukseen kuin siihen, mitä tuona aamuna oli itse asiassa tapahtunut. Tässä mielessä alussa esitetty huomio Internetkeskustelun lyhytjänteisyydestä näyttäisi toteutuneen tässä yksittäistapauksessa.

\section{Kuka piirtäisi viholliskuvan?}

Darwin-sivuston keskusteluryhmässä ei syntynyt kuuden ensimmäisen tunnin aikana selkeää ystävä-vihollinen -asetelmaa ainakaan "nimeämisen politiikan" näkökulmasta. Iskujen mahdollisina tekijöinä pidettiin muun muassa Osama bin Ladenia, PLO:ta ja amerikkalaisia militia-äärijärjestöjä, eikä tätä kautta syntynyt vastakäsiteparia sen suhteen, kenen tai minkä kimppuun oli oikeastaan hyökätty. Keskustelussa ei käytetty kuuden ensimmäisen tunnin aikana kertaakaan esimerkiksi myöhemmin uutiskanavilta ja poliittisesta retoriikasta tutuiksi tulleita ilmaisuja kuten esimerkiksi "War on Terrorism".

Keskusteluryhmän viesteistä voi havaita viitteitä siitä, että aamun iskujen koettiin olleen tapahtuma, joka oli kuin sodanjulistus tai ainakin oikeuttaisi sodan julistamiseen. Samalla kirjoittajille oli epäselvää, ketä vastaan sotaa pitäisi käydä. Halu löytää syylliset tapahtuneelle oli ilmeinen, mutta mitään selkeää vihollisasetelmaa oli vaikea löytää. Muutamissa viesteissä mainittiin henkilö nimeltä "the Bin Laden", mutta tämäkään viholliskuva ei tarkentunut keskustelun edetessä sen kummemmin. Median - suurimmaksi osaksi television - kautta seurattu tapahtumasarja vaikutti keskustelijoista lähes epätodelliselta, ja vertailukohtia haettiin myös fiktiosta:

Tämä on surullista. Vaimoni, joka katsoi televisiota, sanoi, että tämä on kuin katsoisi elokuvaa, Independence Dayta tai jotakin. (Plazz Tekk, klo 12.35.)

Darwin-sivuston keskusteluryhmässä ei kuitenkaan tapahtunut missään vaiheessa mitään selkeää jakoa tyyliin "me vastaan he". Hieman kello kahdentoista jälkeen nimimerkki Salamander2 lähetti ryhmään viestin, jossa hän kritisoi mahdollisen kostoiskun oikeutusta. Hän sai sekä kannattavia että vastustavia kommentteja, mutta missään vaiheessa ryhmässä ei menetetty keskusteluyhteyttä eri näkemysten välillä. Sen sijaan erilaisia näkemyksiä kyettiin sulauttamaan osaksi samaa keskustelua ja pohtimaan rinnakkain. Toisaalta monien kirjoittajien henkilökohtainenkin suhtautuminen tapahtumiin oli valmiiksi kaksijakoinen:

Voin melkein ymmärtää sen, että ihmisiä tapetaan, jotta tämä ei tapahtuisi uudestaan, mutta kosto? Minulla on ystäviä siellä päin (Lähi-itä)... Minun on vaikeaa jakaa tapahtunutta "meihin" ja "heihin". (Vreia, klo 13.31.)

Kuuden ensimmäisen iskuja seuranneen tunnin aikana keskusteluryhmässä oli jatkuvasti esillä keskenään ristiriitaisia mielipiteitä ja näkemyksiä. Ensimmäisten kahden tunnin aikana ryhmään lähetetyt viestit olivat lähinnä henkilökohtaisia surun ja voimattomuuden ilmaisuja tai jonkin faktisen tapahtuman raportointia muille verkkokeskustelun osallistujille. Sen jälkeen terrori-iskuihin liittyvät henkilökohtaiset poliittiset näkemykset ja kannanotot lisääntyivät merkittävästi.

Käytännössä kaikki kello kahden jälkeen ryhmään postitetut viestit sisälsivät pääasiassa kommentteja johonkin toiseen viestiin, eikä "voi Luoja, kuinka tällaista voi tapahtua" -viestien kaltaisia "hätähuutoja" lähetetty enää lainkaan. Sa- 
malla näissä myöhemmissä viesteissä korostettiin sitä, että pahin on tavallaan jo ohi ja asiat tullaan saamaan "kontrolliin":

Elämämme palaa pian normaaliksi, kunhan kaikki on varmistettu. Markkinat tulevat palautumaan normaalitilaan kunhan huomataan, että asioista on huolehdittu tarvittavalla tavalla. (Vladislav, klo 14.43.)

Darwin-sivuston keskusteluryhmän perusteella terrori-iskuja käsittelevään keskusteluun välittömästi tapahtuman jälkeen ja osaksi niiden aikana osallistuneet kirjoittajat eivät olleet missään vaiheessa valmiita omaksumaan kritiikittömästi sittemmin tutuksi tullutta sotatoimien välttämättömyyden retoriikkaa siinä mielessä, että he olisivat kokeneet seisovansa "yhtenä rintamana" jotakin "viholliseksi" määriteltyä vastaan. Osaltaan tähän vaikutti varmasti se, että mitään "virallista" viholliskuvaa ei ollut vielä muodostunut tai muodostettu. Osama bin Ladenin nimi vilahteli keskusteluryhmän viesteissä muutamaan otteeseen, mutta vielä viisi tuntia iskujen jälkeen ryhmässä esitettiin kahteen otteeseen näkemyksiä, että iskut saattaisivat Oklahoman pommi-iskun tavoin olla amerikkalaisten itsensä tekemiä. Tulevaan USA:n sotilaalliseen voimankäyttöön vihjattiin metaforisilla ilmauksilla kuten "kansakunnan raivo" ja "leikin aika on ohi", mutta nämäkään ilmaisut eivät määritelleet voimankäytölle selkeää kohdetta. Samaten monissa viesteissä tehtiin selväksi, että "heille pitää antaa opetus", mutta epäselväksi jäi, keitä "he" oikeastaan ovat.

"Yhteisen rintaman" kaltaisten metaforien sijaan keskustelussa nousivatkin enemmän esiin yksittäisten kirjoittajien henkilökohtaiset elämäntilanteet ja heidän voimattomuutensa käsittää tuon aamun tapahtumia ja niiden vaikutuksia. Monilla kirjoittajilla oli voimakas tarve tehdä henkilökohtaisesti jotakin, mutta samalla heille oli epäselvää, mitä oikeastaan pitäisi tehdä. Ehkä parhaiten tätä asennoitumista kuvaa nimimerkin Dadvocate lähettämä viesti:

Olen ryypännyt jo jonkin aikaa ja yrittänyt selvittää tunteitani... Kaikki tämä viha, verenhimo ja toive siitä, että joku joutuu maksamaan suuresti siitä mitä he ovat tehneet... Slovakiassa asuva tyttöystäväni sanoo ymmärtävänsä vihani, mutta en ole varma, tajuaako hän kuinka paljon minua pelottaa lentää takaisin Slovakiaan. Kaiken tämän kärsimyksen keskellä oma pelkoni nielee minut... En oikeasti tiedä mitä minun pitäisi tehdä. (Dadvocate, klo 14.51.)

\section{Johtopäätöksiä}

Pian käynnistymisensä jälkeen Darwin-sivuston verkkokeskustelu saavutti lähes reaaliaikaisen tason, jossa tapahtumien, niiden uutisoinnin ja verkkokeskusteluviestien aikaväli oli kaventunut marginaalisen pieneksi. Samalla alkoi hahmottua, että kyseessä on yksittäistapahtumien sijaan tapahtumasarja, jonka osat liittyvät jollakin tavalla toisiinsa. Onkin todennäköistä, että tuossa vaiheessa suurin osa keskusteluryhmässä olleista käyttäjistä oli yhtä aikaa jonkin toisen informaatiolähteen (televisio, radio, muut Internet-sivustot) ääressä ja raportoi näkemäänsä keskusteluryhmään, ikään kuin olisi itse ollut paikalla tapahtumien varsinaisena silminnäkijänä. Havaintojakson loppupuolella lähetetyistä viesteistä voi päätellä, että tapahtumien edetessä keskusteluryhmästä tuli keskustelijoille entistä enemmän primäärifoorumi informaation välittämiselle ja vastaanottamiselle ja muut mediat jäivät vastaavasti taka-alalle.

Tutkimusaineiston perusteella voi myös todeta, että keskusteluryhmän "toimintakyky" säilyi tapahtumien shokeeraavasta luonteesta riippumatta. Fyysistä maailmaa etäisempi virtuaaliympäristö ehkä jopa lievensi shokkireaktiota, joka 
olisi saattanut olla voimakkaampi, jos samat ihmiset olisivat seuranneet tuon aamun tapahtumia yhteisessä fyysisessä tilassa. Samalla käsitteellisten metaforien ja metaforisten ilmaisujen kaltaisten "retoristen työkalujen" merkitys tapahtumien käsittämisen välineinä korostui, koska ryhmän keskinäinen kommunikaatio oli kokonaan tekstivälitteistä.

Keskusteluryhmässä ei myöskään syntynyt mitään laaja yhteistä käsitystä esimerkiksi siitä, mikä merkitys tapahtumilla on tulevaisuuden kannalta. Tarkasteltava aikaväli vaikutti varmasti asiaan, mutta viesteistä käy hyvin ilmi se, että kirjoittajilla oli varsin erilaisista lähtökohdista nousevia näkökulmia iskuihin. Tässä mielessä verkkokeskusteluryhmä toimi yhden yhteisen mielipiteen muodostamisfoorumin sijaan enemmänkin yhteisenä "työstämistilana" käyttäjien omalle henkilökohtaiselle suhtautumiselle päivän traagisiin tapahtumiin.

Erityisen mielenkiintoista Darwin-sivuston keskusteluryhmässä on, että siellä esiintyi jo muutama tunti iskujen jälkeen Yhdysvaltain omaan toimintaan kriittisesti suhtautuvia viestejä ilman, että muut ryhmän jäsenet olisivat pyrkineet vaientamaan niiden lähettäjiä. Vaikka keskusteluryhmässä olikin ehkä yhteinen ymmärrys siitä, että tapahtuneet iskut olivat "väärin", sen pohjalta esitettiin lukuisia erilaisia ja keskenään ristiriitaisia argumentteja siitä, mikä olisi sopiva tapa "oikean" tai "oikeuden" toteutumiselle. Verkkokeskustelussa tuli esiin toisistaan hyvinkin poikkeavia näkemyksiä syyskuun yhdennentoista päivän tapahtumista, mutta niistä kyettiin keskustelemaan ryhmässä niin, ettei kenenkään näkemyksiä tyrmätty suoralta kädeltä, vaikka orastavia vastakkainasetteluja esimerkiksi sotilaallisen kostoiskun ja rauhanomaisemman näkemyksen välillä olikin havaittavissa.

Tähän vaikutti varmasti se, että ryhmän osanottajat olivat henkilökohtaisella tasolla sitoutuneet keskusteluryhmän toimintaan tiiviisti ja kokivat sen ikään kuin "omana paikkanaan", jossa voi vaihtaa näkemyksiä ainakin jossakin määrin tuttujen keskustelijoiden kanssa. Osaltaan verkkokeskusteluryhmän toimivuuteen vaikuttivat varmasti myös siihen aktiivisesti kohdistuvat ohjaustoimenpiteet tai ainakin tietoisuus niiden olemassaolosta. Asiattomaksi katsottu keskustelu ja muiden keskustelijoiden henkilökohtainen herjaaminen loppuvat Darwin-sivuston keskusteluryhmissä yleensä alkuunsa joko "ylläpitäjän" tai keskusteluryhmän muiden jäsenten epäsuoran painostuksen ansiosta.

Toimivassa verkkokeskustelufoorumissa tarvitaan palvelun tarjoajan lisäksi foorumin toimintaperiaatteisiin sitoutuneita käyttäjiä ja suvereenia "ylläpitäjää", jolla on toimintavaltuudet puuttua keskustelua haittaaviin tekijöihin kirjoittajien legitiimiksi kokemalla tavalla. Tämä lähtötilanne mahdollistaa osaltaan sen, että ryhmässä käytävä keskustelu voi olla luonteeltaan sekä asiallista että hyvinkin moniarvoista ja näkemyksiltään ristiriitaista. Jos keskustelijat ovat lisäksi etukäteen sitoutuneet perustelemaan omat näkemyksensä ja kunnioittamaan toisten esittämiä ajatuksia, on toimiva erilaisten näkemysten välinen kamppailu- ja pelitila mahdollinen myös verkkokeskusteluympäristössä.

\section{Verkkosivut}

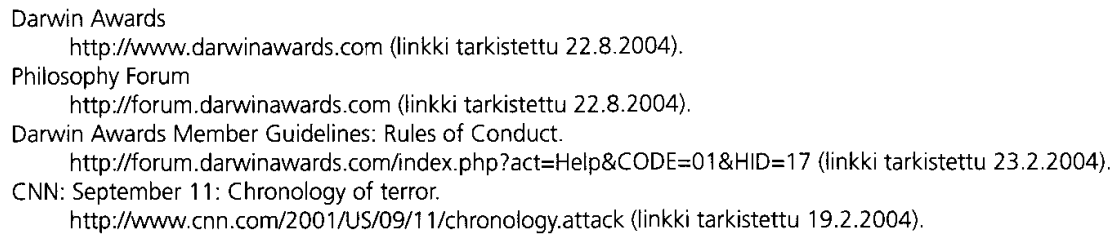




\section{Kirjallisuus}

Aarnio, Eeva, Mikko Jäkälä, Jari Hoffrén \& Pekka Isotalus (2001)

Poliittisen toiminnan uusilla foorumeilla. Teknologiavälitteisyys: edistäjä vai estäjä? Tiedotustutkimus 24:3, 4-18.

Aro, Jari (1999)

Sosiologia ja kielenkäyttö. Retoriikka, narratiivi, metafora. Acta Universitatis Tamperensis 654 .

Cooper, Simon (1997)

Plenitude and Alienation: The Subject of Virtual Reality. Teoksessa David Holmes (toim.) Virtual Politics.

Identity \& Community in Cyberspace. London, Thousand Oaks \& New Delhi: Sage, 93-106.

Edwards, Arthur R. (2002)

The Moderator as an Emerging Democratic Intermediary: The Role of the Moderator in Internet Discussions about Public Issues. Information Polity 7:1, 3-20.

Heim, Michael (1993)

The Metaphysics of Virtual Reality. New York \& Oxford: Oxford University Press

Heim, Michael (1998)

Virtual Realism. New York \& Oxford: Oxford University Press.

Holmes, David (1997)

Virtual Identity: Communities of Broadcast, Communities of Interactivity. Teoksessa David Holmes (toim.)

Virtual Politics. Identity \& Community in Cyberspace. London, Thousand Oaks \& New Delhi: Sage, 26-45

Johnson, David R. \& David G. Post (1998)

The Rise of Law on the Global Network. Teoksessa Brian Kahin \& Charles Nesson (toim.) Borders in Cyberspace. Information Policy and the Global Information Infrastructure. Second Edition. Cambridge, Massachusetts \& London: The MIT Press, 3-47.

Kuusisto, Riikka (1999)

Western Definitions of War in the Gulf and in Bosnia. The Rhetorical Frameworks of the United States, British and French Leaders in Action. Commentationes Scientiarum Socialum 54. Helsingin yliopisto.

Lakoff, George (1993)

The Contemporary Theory of Metaphor. Teoksessa Andrew Ortony (toim.) Metaphor and Thought. Second Edition. Cambridge: Cambridge University Press.

Lakoff, George \& Mark Johnson (1980)

Metaphors We Live By. Chicago: The University of Chicago Press.

Lessig, Lawrence (2001)

The Future of Ideas. The Fate of the Commons in a Connected World. New York: Random House.

Mcintosh, Wayne V. \& Cynthia L. Cates (1997)

Hard Travelin': Free Speech in the Age of the Information Superhighway. Teoksessa Chris Toulouse \& Timothy

W. Luke (toim.) The Politics of Cyberspace. New York \& London: Routledge, 84-118.

Northcutt, Wendy (toim.) (2001)

The Darwin Awards: 180 Bizarre True Stories of How Dumb Humans Have Met Their Maker. London: Orion. Northcutt, Wendy (toim.) (2003)

The Darwin Awards II: 180 More True Stories of How Dumb Humans Have Met Their Maker. London: Orion.

Northcutt, Wendy (toim.) (2004)

The Darwin Awards III: Even More True Stories of How Dumb Humans Have Met Their Maker. London: Orion.

Palonen, Kari (1988)

Tekstistä politiikkaan. Johdatusta tulkintataitoon. Hämeenlinna: Vastapaino.

Palonen, Kari (1998)

Ovatko käsitteet jäädyttäjiä vai jäänsärkijöitä? Teoksessa Tuija Parvikko, Kari Palonen \& Leena Eräsaari (toim.) Politiikka pois paikoiltaan. Juhlakirja Sakari Hänniselle. Jyväskylä: SoPhi, 171-188.

Pekonen, Kyösti (1991)

Symbolinen modernissa politiikassa. Jyväskylän yliopiston nykykulttuurin tutkimusyksikön julkaisuja 25

Peltola, Jari (2000)

Kauriinmetsästäjän kuolema. Helsingin Sanomat, Kuukausiliite. Lokakuu 2000, 19.

Peltola, Jari (2003a)

"Aktiivisen verkkokansaláisen" retorisesta tuottamisesta. Tiedotustutkimus 26:3, 54-62.

Peltola, Jari (2003b)

Kaksi näkökulmaa 2000-luvun teledemokratiaan. Kuittuurintutkimus 20:4, 35-46.

Perelman, Chaim (1982)

The Realm of Rhetoric. Notre Dame: The University of Notre Dame Press.

Pietilä, Veikko (2002)

Verkkokeskusteluareenat - deliberatiivista julkisuuttako? Politiikka 44:4, 343-354.

Raab, Charles (1998)

Privacy, Democracy, Information. Teoksessa Brian D. Loader (toim.) The Governance of Cyberspace. Politics, Technology and Global Restructuring. London \& New York: Routledge, 155-174.

Savolainen, Reijo (1996)

Suurajot vai surmanajot? Internetin keskusteluryhmä keskustelee. Tiedotustutkimus 19:4, 48-65.

Willson, Michele (1997)

Community in the Abstract: A Political and Ethical Dilemma? Teoksessa David Holmes (toim.) Virtual Politics. Identity \& Community in Cyberspace. London, Thousand Oaks \& New Delhi: Sage, 145-162. 